\title{
THE ISSUE OF RESEARCH AND DEVELOPMENT COSTS IN A METALLURGICAL ENTERPRISE WITH THE IMPLEMENTATION OF THE ABC CALCULATION METHOD
}

\author{
Andrea SUŠKOVÁ, Jana BUCHTOVÁ \\ VSB - Technical University of Ostrava, Ostrava, Czech Republic, EU, \\ andrea.suskova@gmail.com, jana.buchtova@vsb.cz
}

https://doi.org/10.37904/metal.2020.3635

\begin{abstract}
This article aims to present different perspectives and their respective advantages in the area of research and development cost integration in an enterprise using a calculation system based on the ABC method and choose optimum implementation the costs research and development. Research and development costs in industrial enterprises are often recorded for the reason of tax breaks secured by valid legislation. They are often neglected in terms of calculations, however, in spite of the fact that they may be substantial sums which the enterprise in many cases does not even translate into the selling price. At the same time, research and development work of a company can pose one of its biggest competitive advantages in this era.
\end{abstract}

Keywords: Calculation method, research, development, metallurgy, implementation

\section{INTRODUCTION}

The current trend of constantly accelerating economic cycles and market globalization across all industries puts a substantial amount of pressure on competitiveness not only for large or multinational companies but also for medium-sized and small firms. Research and development activities are often considered the most significant competitive advantages of such enterprises. They are a part of a comprehensive system of company strategic cost management. In this way, it is also possible to talk about their secondary effect, namely cost optimization in industrial and metallurgical production.

\section{DEFINITION OF RESEARCH AND DEVELOPMENT}

Research and development consist of a very broad range of activities. In consequence, there is no completely uniform or comprehensive definition of these concepts. This is also due to different views and approaches to these activities. The so-called Frascati Manual sets out, in accordance with the D-288 Guideline issued by the Czech Ministry of Finance, basic criteria for differentiating between research and development, namely "the presence of a rateable element of novelty and clarification of research and technical uncertainty" [1]. Income Tax Act No. 586/1992 Coll. as amended defines research and development costs (expenses) as "expenses (costs) which the taxpayer deducts from the base tax amount from the date of submitting the intention to deduct from the tax base to support research and development in the realization of research and development projects for 1. experimental of theoretical work, 2. design and construction work, 3. calculations, 4. technology design, 5. production of a functional sample or prototype of a product or its part(s) related to the realization of a research and development project." Furthermore, it defines the means of recording such expenses (costs) as well as expenses (costs) which cannot be considered as research and development costs (expenses) under this Act. Further views and clarification of the term "research and development" are offered by accounting and tax legislation, formally regulated by the Accounting Act No. 593/1991 Coll., which defines the individual types of costs that can be considered from the accounting and tax point of view as research and development costs together with their accounting and reporting methods. It is also necessary to take into account the procedure protocol for the accounting act for entrepreneurs, which, effective from January 1, 2018, deleted the item 
"research" from a list of intangible fixed assets on the basis of Directive 2013/34/EU and left only "development". This provision is supplemented by Czech Accounting Standards Nos. 013 and 017. When defining these areas in practice, companies usually follow the International Accounting Standards (IAS/IFRS), in particular IAS 38. This standard defines research as "original and planned research carried out with the objective of acquiring new scientific or technical knowledge" while defining development as "use of research results or other knowledge to plan or develop new or substantially improved materials, devices, products, processes, systems or services, prior to commencement of their commercial production or use." [2]. When we consider the conclusions in the Interpretation No. 40 of the Czech National Accounting Council - Reporting of Intangible Results of Research and Development, it is clear that the standpoint contained therein corresponds with the aforementioned IAS 38 standard. This interpretation specifies the definitions of "research as original and planned research carried out with the objective of acquiring new scientific or technical knowledge, whereas development is defined as use of research results and other knowledge with the purpose of planning or designing new or substantially improved materials, devices, products, processes, systems or services, prior to commencement of their commercial production or use." [7] The interpretation No. 40 also defines methods of registering, accounting, and depreciation of research and development costs. However, the issue introduced has a much greater impact than just tax, as it might seem at first glance. It significantly affects the company's financial position, assets, disposable profit, and, finally, company calculations. For calculations, the managerial concept of research and development costs is used. They are understood in a broader context, in contrast with financial statements and transactions that serve as a source of data. The last variant mentioned, calculation, it the subject of this article.

\section{MANAGERIAL CONCEPT OF RESEARCH AND DEVELOPMENT COSTS}

As is apparent from the aforementioned legislative requirements, research costs cannot be capitalized as intangible fixed assets (IFAs) as they do not meet the asset characteristics provided by law, partly due to uncertainty regarding the research outcome. Research costs must therefore be considered as expenses in an accounting period. On the other hand, development costs can be capitalized as IFAs and further depreciated, if the conditions set have been met. These differences in accounting and registration subsequently affect economic results as well as income tax. This particular aspect will be thoroughly explained in a case study. The basic criterion for the managerial view of research and development costs is cost differentiation based on 1. degree of dependence on the volume of performed tasks and 2. calculation breakdown. In the first case, we distinguish between variable and fixed costs, whereas in the second one the costs are divided into one-off costs and overheads. [3]. In order to evaluate of research and development costs, we must use the values recorded in accounts. However, it is necessary to approach these costs not only through the optics of legislative requirements on research and development costs as mentioned above, but also through a procedural point of view. In practice, this means that we also add other costs to R\&D that are not primarily defined as research and development costs but are closely involved in and have influence on research or development of the contract or item itself. When implementing the ABC calculation method in an enterprise, different procedures for research and development cost allocation may arise due to the facts mentioned above. This issue is addressed in this article.

\subsection{Activity Based Costing calculation}

The $A B C$ is a process-oriented calculation method that assigns costs to individual activities. The goal of this calculation method is to identify true causes of costs and to allocate overhead costs to activities performed, on the basis of which they are subsequently assigned to cost objects [4]. This is where different views on research and development costs may arise, as development costs are influenced by customer demands, whereas research costs are realized completely independently of any specific customer requirements. From this point of view, R\&D costs are in both cases assigned to different types of costs during calculation, although they are always regarded as fixed costs by the primary distinction. However, the causal aspect specifies the allocation 
of these costs in more detail. This entirely different concept requires the creation of $A B C$ calculation on the basis of different assignment of R\&D costs. The case study included in this article will show the differences in the abovementioned R\&D cost allocation methods in practice.

\section{CASE STUDY}

A certain metallurgical company that was selected for the purposes of this case study has managed to build its own development facility over the years, employing a team of highly skilled professionals. This development facility has at its disposal the necessary technological background for material research. The costs of this cost centre are assigned directly to it. For the purposes of this study, the cost centre was named "Development". However, employees of other cost centres, such as technology and/or construction, can also be involved in development. In some cases, the company management decided to cooperate on the project with an external supplier of technical documentation. This is the situation that was selected for the purposes of creating a calculation model in this case study. It concerns development of a new type of material for castings according to parameters required by a customer with a contract for 5 years. The fact that the assignment of development work was based on customer requirements defines the nature of the costs. We are therefore dealing not with research costs, but with development costs. As the first step, it is therefore necessary to decide which costs are to be included in the total development costs and which should be excluded.

\subsection{Analysis of costs in question}

Data acquired for the purposes of cost analysis were assigned to the "Development" cost centre for the period in which this cost centre was tasked with realization of the development project in question. This concerns material consumption, energy consumption, labour costs, depreciation, other operating costs, operation material, services and intangible fixed assets in form of technical documentation obtained under a contract from an external supplier. A more detailed look at partial cost categories gives us room for their thorough analysis and subsequently allows us to decide whether or not to leave them in the category of total development costs. Material consumption - all material used directly for construction of a new type of material for castings in development. Energy consumption - these costs are partly direct energy consumption (energy used by technologies and machines) and partly indirect energy consumption for common premises and buildings of the "Development" cost centre. Labour costs - or personnel costs that include wages of both laborers and technicians of the "Development" cost centre together with statutory tax. Depreciation - reported value includes only depreciation of technologies and machines used by the "Development" cost centre. Other operating costs - this particular type of costs includes property insurance and fees of the "Development" cost centre. Operation material - this includes workwear, small tools, fuel, office supplies etc. used by the "Development" cost centre. Services - services include travelling or representation costs together with rent, repairs and external costs of development and production of a prototype. In this particular case, the costs under this bracket partly consist of accrued external costs of research and development of a project other than the one addressed in this case study, which amount to 520 thousand CZK. Intangible fixed assets (IFAs) their total value derives from externally supplied technical and construction documentation for the development project in question. Personnel costs of the Technical Department (TD) - personnel costs of constructors and technicians involved in the development project in question described in this case study, together with statutory tax. The value of these personnel costs was determined from accounting records.

\subsubsection{Accounting and tax differentiation of development costs}

If we are to adhere to legislative requirements for quantifying and adjustment of research and development costs, we need to make the following changes. In particular, it is necessary to exclude part of the costs from Services, as they are related to another development project as described above. The costs thus excluded amount to 520 thousand CZK. Of the total amount of accounting costs of the "Development" cost centre after legislative amendments, only 21,417 thousand of CZK remain as costs of the development in question. 
Employees of the Technical Department (TD) - designers and technologists - were also partly involved in the development project in question. Therefore, in order to calculate total value of costs of the development project and valuation of the intangible asset, it is necessary to calculate their share in the form of personnel costs with a causal link to the project in question. These costs amount to 1,930 thousand CZK. The structure of these costs is as shown in Table 1. Adjustments are marked with an arrow.

Table 1 Total structure of costs for development project according to accounting and tax legislation (in thousands of CZK).

\begin{tabular}{|c|c|c|c|c|}
\hline \multicolumn{2}{|r|}{ Cost type } & Book value & $\begin{array}{l}\text { Value } \\
\text { excluded }\end{array}$ & $\begin{array}{c}\text { Final cost } \\
\text { value }\end{array}$ \\
\hline \multirow{8}{*}{$\begin{array}{l}\text { "Development" cost } \\
\text { centre }\end{array}$} & Material consumption & 3,528 & & 3,528 \\
\hline & Energy consumption & 198 & & 198 \\
\hline & Operation material & 166 & & 166 \\
\hline & Personnel costs & 5,772 & & 5,772 \\
\hline & Depreciation & 3,408 & & 3,408 \\
\hline & Other operating costs & 13 & & 13 \\
\hline & Services & 1,096 & 520 & 576 \\
\hline & IFA & 7,756 & & 7,756 \\
\hline \multicolumn{2}{|c|}{ Total "Development" costs } & 21,937 & 520 & 21,417 \\
\hline "TD" cost centre & Personnel costs & 1,930 & & 1,930 \\
\hline \multicolumn{2}{|c|}{ Total "TD" costs } & 1,930 & & 1,930 \\
\hline \multicolumn{2}{|c|}{ Development costs IN TOTAL } & 23,867 & 520 & 23,347 \\
\hline
\end{tabular}

Total cost value of the development project in question therefore amounts to 23,347 thousand CZK. This value is further capitalized as an intangible fixed asset and depreciated in accordance with applicable law and internal accounting guidelines of the company. The Income Tax Act specifies the minimum depreciation period for development costs as 36 months. Annual depreciation value will amount to 7,782 thousand CZK. If we consider the same costs from a managerial point of view, changes can be made in a different way.

\subsubsection{Managerial differentiation of development costs}

The difference in the managerial concept of costs may arise from a different view of the entire development process, as it is considered through the optics of life cycle of the resulting product. The product lifecycle also takes into account costs incurred at various stages of design and performance preparation [5]. For this reason, costs of the development project are supplemented with the value of technical provision of the project from the previous financial year, which amounts to 1,200 thousand CZK. Another adjustment is made by adding the value of energy consumption of common areas for the duration of the realization of the development project, as well as value of depreciation of buildings in which the development project was being realized. In total, this amounts to 2,645 thousand CZK. The last adjustment to the total value of the development project concerns exclusion of costs which are not closely related to the development project in question, i.e. are fixed in relation to activities of the whole "Development" cost centre. In this case study, these are only operating costs which include, as stated in paragraph 4.1, property insurance and one-off fees. The costs omitted in this way amount to 13 thousand CZK. All cost adjustments are indicated in Table 2 together with their respective descriptions. The total value of the costs of the development project amounts to $27,179 \mathrm{CZK}$, which is $3,832 \mathrm{CZK}$ more than in the previous case referred to in paragraph 4.1.1.

The approach to depreciation of these costs after their capitalization as IFAs will also be different. Depreciation will take place on the basis of length of the contract that stood at the beginning of this development project 
and de facto started it. The length of said contract was set at 5 years. This figure also serves as schedule basis for depreciation of total IFA value of the development project. In this case, the value of annual depreciation will amount to 5,436 CZK. Both of these different approaches - accounting and managerial - are important mainly because both serve a different decision-making purpose, and both pose as a starting point for different calculations. For the purposes of this article, only managerial approach will be used, as we will further consider integrating these costs into activity structure and later cost matrix in the $A B C$ calculation.

Table 2 Total cost structure for development project from managerial point of view (in thousands of CZK)

\begin{tabular}{|c|c|c|c|c|c|c|}
\hline \multicolumn{2}{|c|}{ Cost type } & \multirow{2}{*}{$\begin{array}{r}\begin{array}{l}\text { Book } \\
\text { value }\end{array} \\
3,528 \\
\end{array}$} & \multirow{2}{*}{$\begin{array}{l}\text { Value } \\
\text { excluded }\end{array}$} & \multirow[t]{2}{*}{$\begin{array}{l}\text { Value } \\
\text { added }\end{array}$} & \multirow{2}{*}{$\begin{array}{r}\begin{array}{c}\text { Final } \\
\text { cost } \\
\text { value }\end{array} \\
3,528 \\
\end{array}$} & \multirow{5}{*}{$\begin{array}{l}\text { energy consumption of buildings } \\
\text { during project realization }\end{array}$} \\
\hline \multirow{8}{*}{$\begin{array}{l}\text { "Development" } \\
\text { cost centre }\end{array}$} & Material consumption & & & & & \\
\hline & Energy consumption & 198 & & 60 & 258 & \\
\hline & Operation material & 166 & & & 166 & \\
\hline & Personnel costs & 5,772 & & & 5,772 & \\
\hline & Depreciation & 3,408 & & 2,585 & 5,399 & \multirow{4}{*}{$\begin{array}{l}\text { depreciation of buildings during } \\
\text { project realization } \\
\text { technical support for the project - } \\
\text { accruals }\end{array}$} \\
\hline & $\begin{array}{l}\text { Other operating } \\
\text { expenses }\end{array}$ & 13 & 13 & & 0 & \\
\hline & Services & 1,096 & 520 & & 576 & \\
\hline & IFA & 7,756 & & 1,200 & 8,956 & \\
\hline \multicolumn{2}{|c|}{ Total "Development" costs } & 21,937 & 533 & 3,845 & 25,249 & \\
\hline $\begin{array}{l}\text { "TD" cost } \\
\text { centre }\end{array}$ & Personnel costs & 1,930 & & & 1,930 & \\
\hline \multicolumn{2}{|c|}{ Total "TS" costs } & 1,930 & & & 1,930 & \\
\hline \multicolumn{2}{|c|}{ Development costs IN TOTAL } & 23,867 & 533 & 3,845 & 27,179 & \\
\hline
\end{tabular}

\subsection{Placement of development costs into $A B C$ calculation structure}

The placement the costs to development is problematic point often in the $A B C$ structure. The basic $A B C$ structure distinguishes between primary and supporting activities. Differentiating activities into these two groups is essential for creating cost matrices for activities as well as other steps included in this method. All this has a significant impact on calculations of costs of individual activities, determination of performance consumption for supporting activities and subsequent cost allocation [6]. When considering placing development costs in the $A B C$ structure, multiple possibilities arise, from which two will be presented. Variant 1 - Costs of the "Development" centre will be included in the structure primarily as a supporting activity and only a part of development costs of the project in question will be allocated to become a part of the primary activity named "Technical support of production". When applying the ABC method, the cost value of the development project, as primary activity, would affect performance of the entire "Technical support of production" and would be allocated to the cost centre. Remaining costs of the "Development" centre, as supporting costs, would be assigned proportionally to other primary activities. This approach is demonstrated by a simple $A B C$ calculation structure as shown in Table 3 .

Table 3 Classification of development project costs as primary activities

\begin{tabular}{|c|c|c|c|c|}
\hline \multicolumn{4}{|c|}{ PRIMARY ACTIVITIES } & SUPPORTING ACTIVITIES \\
\hline Initial logistics & Customer process & $\begin{array}{c}\text { Technical support of } \\
\text { production }\end{array}$ & Production process & Supporting activities \\
\hline $\begin{array}{l}\text { Ordering } \\
\text { Receipt of } \\
\text { material } \\
\text { Storage }\end{array}$ & $\begin{array}{l}\text { Customer service } \\
\text { Acquisitions } \\
\text { Expeditions }\end{array}$ & $\begin{array}{l}\text { Technical documentation } \\
\text { Technological procedures } \\
\text { Development project }\end{array}$ & $\begin{array}{l}\text { Production planning } \\
\text { Forming } \\
\text { Melting } \\
\text { Tarnish removal } \\
\text { Metalworking } \\
\text { Quality control }\end{array}$ & $\begin{array}{l}\text { Economic and personnel } \\
\text { IS support } \\
\text { Machine maintenance } \\
\text { Building repairs and } \\
\text { maintenance } \\
\text { Solving equipment failures } \\
\text { Development }\end{array}$ \\
\hline
\end{tabular}


Variant 2 - Costs of the development project will be included in total costs of the "Development" cost centre which in turn will be included among supporting activities in the ABC structure. The total costs of the "Development" centre including costs of the development project, as supporting activities, will thus be allocated to primary activities (Table 4).

Table 4 Total costs of the "Development" centre designated as supporting activities

\begin{tabular}{|c|c|c|c|c|}
\hline \multicolumn{4}{|c|}{ PRIMARY ACTIVITIES } & SUPPORTING ACTIVITIES \\
\hline Initial logistics & Customer process & $\begin{array}{c}\text { Technical support of } \\
\text { production }\end{array}$ & Production process & Supporting activities \\
\hline $\begin{array}{l}\text { Ordering } \\
\text { Receipt of material } \\
\text { Storage }\end{array}$ & $\begin{array}{l}\text { Customer service } \\
\text { Acquisitions } \\
\text { Expeditions }\end{array}$ & $\begin{array}{l}\text { Technical documentation } \\
\text { Technological procedures }\end{array}$ & $\begin{array}{l}\text { Production planning } \\
\text { Forming } \\
\text { Melting } \\
\text { Tarnish removal } \\
\text { Metalworking } \\
\text { Quality control }\end{array}$ & $\begin{array}{l}\text { Economic and personnel } \\
\text { IS support } \\
\text { Machine maintenance } \\
\text { Building repairs and maintenance } \\
\text { Solving equipment failures } \\
\text { Development }\end{array}$ \\
\hline
\end{tabular}

The way development costs are included in primary or supporting activities in the $A B C$ activity structure has a significant impact on allocation of these costs which will ultimately become reflected in the difference in cost values generated by different groups of products and activities.

\section{CONCLUSION}

The limited scope of this article does not allow for demonstration of additional problematic points arising from inclusion of research and development costs in enterprise calculations. It is also impossible to consider the entire calculation process in more detail. The purpose of this article was to highlight the differences in approaches to these types of costs as well as the need for a cautious approach when choosing the type of costs classified between research or development costs and their differentiation. Due to inconsistent and questionable legislative requirements as well as a rather vague definition of these costs, it is necessary to approach this matter with great caution. However, when it comes to calculations, it is necessary to take into account primarily the output of the calculation we intend to use, i.e. what decision-making purpose our calculation will serve.

\section{ACKNOWLEDGEMENTS}

\section{This article was supported by specific university research of the Ministry of Education, Youth and Sports of the Czech Republic at VŠB-TU Ostrava No. SP 2020/61.}

\section{REFERENCES}

[1] Vymezení a účtování nákladů na výzkum a vývoj pro účely daňového odpočtu (Prof. Ing. Libuše Müllerová) - PDF Free Download. Představujeme Vám pohodlné a bezplatné nástroje pro publikování a sdílení informací. [online]. Copyright @ DocPlayer.cz [cit. 11.08.2020]. Dostupné z: https://docplayer.cz/243576-Vymezeni-a-uctovani-nakladu-na-vyzkum-a-vyvoj-proucely-danoveho-odpoctu-prof-ing-libuse-mullerova.html

[2] České znění IFRS (překlad EU) - KOMORA AUDITORŮ ČESKÉ REPUBLIKY. KOMORA AUDITORŮ ČESKÉ REPUBLIKY [online]. Copyright @ 2012 [cit. 11.08.2020]. Dostupné z: https://www.kacr.cz/ceske-zneni-ifrs-preklad-eu

[3] GUTSCHELHOFER, A., ROBERTS, H. Anglo-Saxon and German Life-Cycle Costing. The International Journal of Accounting. 1997, vol. 32, No. 1, pp. 23-44.

[4] POPESKO, B., Modern Methods of Cost Management. Grada Publishing, a.s., 2009. ISBN 978-80-247-2974-9.

[5] ŠOLJAKOVÁ, L., Kalkulace životního cyklu produktu a její využití v řízení nákladů. This article was prepared as one of the outputs of the Development of Accounting and Financial Theory and its Application in Practice from an Interdisciplinary Point of View research project, registration number MSM6138439903.

[6] DRURY, C., Management and Cost Accounting, $8^{\text {th }}$ Edition, British Library Cataloguing-in-Publication Data, 2012. ISBN 978-14080-4180-2.

[7] Schválené interpretace NÚR - Národní účetní rada. Národní účetní rada - Oficiální stránky Národní účetní rady [online] Copyright @ 2020 [cit. 11.08.2020]. Dostupné z: https://nur.cz/interpretace/schvalene-interpretace/ 